\title{
Exploring Innovative Teaching Techniques in Higher Institutions in Cameroon - A Case Study of the Catholic University Institute of Buea, The Growth Entrepreneurial Mindset University
}

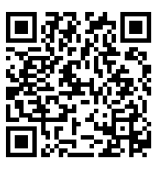

\author{
Evaristus Nyong Abam ${ }^{1 *}$ and Tanyi Bedolf Epey ${ }^{2}$ \\ ${ }^{1}$ Catholic University Institute of Buea, International hospitality management, UK
}

${ }^{2}$ Department of tourism and hospitality management, Catholic university institute of Buea, UK

Submission: November 20, 2019; Published: December 05, 2019

*Corresponding author: Evaristus Nyong Abam, Catholic University Institute of Buea, international hospitality management, UK

\begin{abstract}
Innovative or creative teaching is known to nurtures students' creative potential and this requires four competencies namely learning, social, educational, and technological which involves the preparedness and readiness to learn, communicate with others from different backgrounds, passion and knowledgeability, and finally the use of technology to further student understanding. While there are clearly significant benefits to innovative teaching methods, there is a need for caution too in our fast-paced digital world where students have an extensive amount of visual information to hand throughout the day and night. Selflessness is also a factor when trying to innovate and innovation is not carrying a single idea to a predetermined destination and at some point, innovation must be inclusive. The Catholic University Institute of Buea (CUIB) as a professional university has taken the bold step to be the premier game changer and leader in entrepreneurial education in Cameroon and one thing is certain, that entrepreneurialism does not mean a compromise of traditional academic values. On the contrary, it not only fosters it but elevates it since it requires higher order thinking skills such as problem solving; creativity, critical thinking, and thinking for understanding and transfer. CUIB do not only teach students the tasks and practices of business (Heart of Business) but also help them to develop a moral compass (soul of Business) that will enable them to find the right solutions even when in uncharted territory with a growth mind-set.
\end{abstract}

Keywords: Entrepreneurship; Innovative teaching; Teaching

\section{Introduction}

Traditional lectures is known to have ruled auditoriums for decades however there are new styles of teaching that have been discovered and are being discovered and these newer and more innovative teaching methods are moving away from the traditional model of lecturing and passive learning towards a greater focus on active learning, whereby students flexibly interact with others as they do participate in the lectures. Studies proposed that the collaborative way of learning in primary schools, where children sit around a table to work out a problem together, holds significant benefits for active learners but can become lost as the student progresses through their education. Paradoxically, as students develop superior thinking skills and problem-solving skills, the existing teaching methods becomes more and more passive with time thus leading to disengagement and frustration. The traditional lectures limit the opportunities for student interaction, but recent attempts to provide greater student interactions in lectures have resulted in much higher satisfaction, higher thinking skills and enhanced motivation.
According to the president of the Catholic University Institute of Buea (CUIB), Rev. Dr. George Nkeze Njingwa, most traditional universities are too "content" based and do not allow for the transfer of knowledge, new ideas and technology from university to the industry or community. This is what is popularly known as the Triple Helix Concept, namely the University as the Knowledge base, working with the Industry and Society. It is for this reason that CUIB runs a four-year entrepreneurial programme which is mandatory for all students and the purpose of this programme is to foster innovation, creativity, new ideas and new businesses. Students belong to entrepreneurial base groups and are expected to start their own businesses and run them.

\section{Background of Study}

The Catholic University Institute of Buea (CUIB) South West Region, Cameroon, was approved as a non-profit making university in two separate letters. The authorization to create 
CUIB on 09/01/0194 of 11 June 2009 and the authorization to start was signed by the Honourable Minister of Higher Education Prof Jacque Fame Ndongo by decision no 10/02173/N/ MINSUP/DDES/ESUP/SAC/NJE/ebm dated 26th of May 2010. Its primary purpose is to train professional servant leaders with moral and spiritual values so that they may be responsible to their communities. The proprietor/chancellor of the Catholic University of Buea is the Bishop of the Diocese of Buea. In June 2011, another arm of the University, the Business and Research Park was created as a legal entity of its own by the Cameroon laws no RC BUC.2031-B023 with the name CUIB-Centre for entrepreneurship research and innovation [1]. The Catholic University Institute of Buea Sport Academic (CUSA), Went operational in December 2014 with authorization no 1106/ G37/C84/VOL II/SAAJP with the main aim of assisting young, talented and excellent skilled Cameroonians in the various field of sport like football, volleyball, basketball, handball etc.

\section{Literature Review}

Innovative teaching is the process of leading to creative learning, by implementing new methods, tools and contents that can benefit learners and their creative potential. Instructors, trainers and teaching assistants' relapse to educating students in the way they were educated and thus implementing the teaching practices that were effective in helping them learn furthermore how students learn best has change as time too has change [2]. Sternberg \& Lubart [3] proposed that divergent thinking and embracing alternate solutions to problem solving while demonstrating a sensitivity to problems could help educators achieve these goals. Additionally, it has also been recommended that providing opportunities for active learning and stimulating learning interests could also help nurture innovative practices in the learning environment. Project-based learning is a good example of innovative learning, but it is possibly not the way you would expect as learning through projects is indeed innovative compared to teacher-led and textbook-sourced instruction.

Innovative teaching is good, whether technology is used; as a bad teacher does not suddenly become a good teacher just because technology is not included into the mix nor does a good teacher need to always use technology to maintain their effectiveness. Innovative teaching therefore focuses on creating conducive environments within which good learning can occur and the innovative teachers are excellent at supporting students and are also expert at creating engaging content and new experiences and they measures progress without causing any stress to the learner.

\section{Research Methodology}

For this research work, the researchers used both primary and secondary data that is information collected from fieldwork through direct observation and through books and the website of the University respectively. This research also uses quantitative or qualitative method of data collection and according to
Jary \& Jary [4], qualitative techniques rely on the skills of the researcher as an interviewer or observer in gathering data whereas quantitative methods place reliance upon research instruments employed to gather data and analyze it for example questionnaires.

\section{Findings and Analysis}

According to Rev. Dr. George Nkeze cited in the 2018/2019 bulletin annual publication of the Catholic University Institute of Buea, the dynamics of a constantly changing world is complicated: the education landscape is constantly changing, the old ways of learning- going to school and writing a test is no longer tenable and therefore it will essential to train students and adults about how to learn efficiently (skills oriented) and not what to learn (knowledge oriented). The Catholic University Institute of Buea - CUIB ubiquitous satellite campus: study anywhere, anytime campus is an initiate to take advantage of the technology advances that permit the blend of e-learning with the university's traditional learning methods and models. This model involves a hybrid form of on-site and ubiquitous learning where students, professionals as well as non-professionals alike can benefit from the university state of-the-art and many amenities it provides. The university authorities believe that gone are those days where learning is confined to a physical classroom or restricted to hours of the day as this method contributes to the university's goal to train individuals that can flourish in a rapidly changing world.

According to Kasey Bell [5] google classroom is designed to help teachers and students communicate and collaborate, manage assignments paperless, and stay organized and borrowing from the Google classroom which is part of the Google Apps for education suite, the authorities of the Catholic University Institute of Buea in an effort to continue to foster its policy of on-site and ubiquitous learning. It should be noted that students, professionals as well as non-professionals learn from the comfort of their environment without necessarily meeting in a physical environment and working with the guidance and support of the lecturer. The entrepreneurship training and practice program and activities which provide the scope and tradition necessary to implement the learning processes inherent in building an entrepreneurial mind-set [6].

The Catholic University Institute of Buea - centre for entrepreneurship and innovation academic fair (CUIB-CEI). It is an annual flagship event organised within the first two quarters of the month, it is under the theme 'Economy of Communion'. There are also other innovative teaching methods namely: colloquium guest speaker, academic boot camps and start-ups, business plan challenge contest, one eagle one talent initiative and student incubator program [7].

\section{Conclusion}

As the educational environment is constantly changing in this complicated landscape especially with regards to the 
changing technology, for educational institutions to remain competitive, authorities must move from a fixed mind-set to a growth mind-set [8-11]. This means that they should be able to embrace challenge, be an opportunity to grow and be persistent in the marketplace, learn and identify areas to inform gained more skills from hard work and always accept continuous improvement.

\section{References}

1. Atem G (2014) The unquenched candlelight, Anucam Buea.

2. Zhu C, Wang D, Cai Y, Engels N (2013) What core competencies are related to teachers' innovative teaching? Asia-Pacific Journal of Teacher Education 41(1): 9-27.

3. Sternberg RJ, Lubart TI (1999) The concept of creativity: Prospects and paradigms - handbook of creativity. Cambridge University Press, New York, NY. p. 3-15.

4. Jary D, Jary J (1991) Dictionary of Sociology, Glasglow.
5. Kasey Bell (2015) Teacher's Guide to Google Classroom Shake Up Learning.

6. Abam EN (2016) Examining the Corporate Social Responsibility of the Catholic University Institute of Buea (CUIB) - The Entrepreneurial University. J Tourism Hospit 5: 242.

7. Abam EN (2018) Branding as a means of positioning itself in the marketplace-a case study of the Catholic University Institute of Buea - the Entrepreneurial University: British Journal of Multidisciplinary and Advanced Studies 2(3): 49-53.

8. Abam EN (2016) Examining the Strength of Diversity in the Catholic University Institute of Buea (CUIB) - The Entrepreneurial University. J Tourism Hospit 5: 255

9. (2013-2014) Catholic University Institute of Buea - the entrepreneurial university, Bulletin, Destiny print, Bamenda.

10. (2015-2016) Catholic University Institute of Buea - the entrepreneurial university, Bulletin, Destiny print, Bamenda.

11. (2018-2019) Catholic University Institute of Buea - the entrepreneurial university, Bulletin, Destiny print, Bamenda.

Your next submission with Juniper Publishers
will reach you the below assets
- Quality Editorial service
- Swift Peer Review
- Reprints availability
- E-prints Service
- Manuscript Podcast for convenient understanding
- Global attainment for your research
- Manuscript accessibility in different formats
( Pdf, E-pub, Full Text, Audio)
- Unceasing customer service
Track the below URL for one-step submission
https://juniperpublishers.com/online-submission.php

